\title{
Soil Erosion Hazard in Errer Dembel Sub-Basin, in Shinille Zone of the Ethiopia Somali Regional State
}

\author{
Yohannes Gerezihier Gebremedhin* \\ Department of Natural Resources Management, Adigrat University, Ethiopia
}

Submission: January 10, 2019; Published: February 05, 2019

*Corresponding author: Yohannes Gerezihier Gebremedhin, Department of Natural Resources Management, College of Agriculture and Environmental Sciences, Adigrat University, p.o.x., 50 Adigart, Tigray, Ethiopia

Abstract

Human activities disturb the land surface of the earth, and thereby alter natural erosion rates. Errer-dembel sub-basin is located within awash-basin in Shinille zone of the Ethiopia Somali region. Soil erosion hazard and land degradation were comprised from field measurements, survey and investigation of the area were made. Various forms of erosion and land degradation exist in the basin with varying level of severity and extents were found. The types of land degradation observed in the basin include water erosion, wind erosion, soil fertility decline, sedimentation/soil burial, de-vegetation and rock outcrop. the causes to these include poor farming practices, overgrazing in the range lands, clearing of forest for charcoal making and animal feed, forest and bush burning and lack of awareness. A maximum soil loss of $40.80 \mathrm{tha}^{-1} \mathrm{yr}^{-1}$ and minimum of 0-3 tha $^{-1} \mathrm{yr}^{-1}$ is estimated in the sub-basin. Similarly, the soil loss tolerance limit estimates, indicated high values 7 tha $^{-1} \mathrm{yr}^{-1}$ for the high rainfall areas with intensive cultivation, and low values of $1-4$ tha $^{-1} \mathrm{yr}^{-1}$ in the low rainfall areas in the north of the basin, owing to the prevailing unfavorable conditions involved in soil formation processes. Soil formation rate is in the range of $0.5-4$ tonsha $^{-1} \mathrm{yr}^{-1}$. This indicates that the soil loss is much beyond the tolerable level in the southern and south eastern part of the sub-basin with the resultant high index of erosion hazard. Thus, the soils of Errer-dembel sub-basin are found to be highly susceptible to soil erosion under any circumstances.

Keywords: Soil erosion hazard; Soil erosion; Soil degradation; Errer-dembel sub-basin; Ethiopia Somali regional state

\section{Introduction}

Soil erosion, land degradation and desertification are terminologies commonly employed in describing the condition of an environment that is in disequilibrium and mainly are the result of man's interaction with his surroundings. Accelerated soil erosion is often a problem where unsystematic or inappropriate land use prevails and can simply be defined as the process of removal or displacement of soil particles from one place to another by the forces of water and/or wind and mass slide. The continues removal of soil particles from a given area often leads to the complete removal of the nutrient rich top soil, reduction of the soil depth and its water holding capacity and thus in turn lead to reduced productivity [1].

Varieties of human activities disturb the land surface of the earth, and thereby alter natural erosion rates [2]. Land degradation, according to the United Nations' Environmental Program's (UNEP's) definition of 1991 [3], implies reduction of resource potential by one or a combination of processes acting on the land. These processes include water erosion, wind erosion and sedimentation by those agents, long-term reduction in the amount or diversity of natural vegetation or decrease of crop yield where relevant and salinization and sodification of soils. Therefore, soil erosion is the major causes of land degradation in Ethiopian in general and Errer-dembel sub-basin area in particular.
Soil loss rates for different land unit classes (land cover types) were estimated using the Universal Soil Loss Equation (USLE) adapted for Ethiopian conditions. Hurni [4] noted that these results correlated well with test-plot measurements made by the Soil Conservation Research Project (SCRP), although, as noted previously, such estimates can greatly overstate the net impact of erosion on soil loss, because of re-deposition of soils elsewhere in the landscape.

Hurni reports [4] gross soil losses and hence the loss figures are not net of soil re-deposition and soil formation. Soil formation was separately reported so that gross losses could be compared to soil formation, as an indicator of sustainability. Estimation of soil formation was "based on assumptions of soil regeneration as a function of geology and soils (unit and depth), slope gradient, climate (temperature, rainfall, and length of growing period), and land use" [4]. Hurni also noted that the model was not validated thoroughly with field data.

Water erosion is the dominant form of soil erosion in the Errer-dembel sub-basin. Slight wind erosion problem exists particularly on the central and north west of the sub basin around Aysha-Dewele watershed of the sub basin. Accelerated erosion is caused by the activities of man and is responsible for depleting soil productivity, destroying land and filling reservoirs with sediments. 
This review was aimed at assessing the rate soil erosion hazard in Errer dembel sub-basin, in Shinille zone of the Ethiopia Somali regional state, for assessing constraints to development in soil conservation and proposing strategies for effective implementation of the development programme in sub-basin.

\section{Materials and Methods}

\section{Study area description}

Eere-dembel Sub-Basin is located within Awash-Basin bounded between 1029241-1227630UTM N and 686844985384UTM E. The Sub-Basin is found in Shinille Zone of the Somali regional state covering a total area of 2,913,600ha. Based on the land use dynamism and meet the required scale of 1:50,000 scales, Eere-dembel sub-basin is divided in to sub watersheds, namely: Shinile-dembel, and Ayisha, sub watersheds. Shinille, which is the administrative capital of Shinile zone, is $523 \mathrm{~km}$ far away from Addis Ababa towards the east direction and about $167 \mathrm{~km}$ far away from Jigjiga which the capital is cite of Ethiopia Somali region.

Soil erosion hazard and land degradation were comprised from field measurements, survey and investigation of the area, interviewing key informants and households, group discussions with the communities in the basin, collection of relevant secondary data, review of literature and documents and analysis of data. The data and information's collected in the field was compiled and analyzed. Moreover, climate, soil, land use/land cover, slope, farming practice and other factors were analyzed and used in soil erosion and land degradation assessment. The Universal Soil Loss Equation (USLE) is applied for estimating soil loss. Soil formation rates and soil loss tolerance estimates are made using the methods suggested by Hurni [5] (Figure 1).

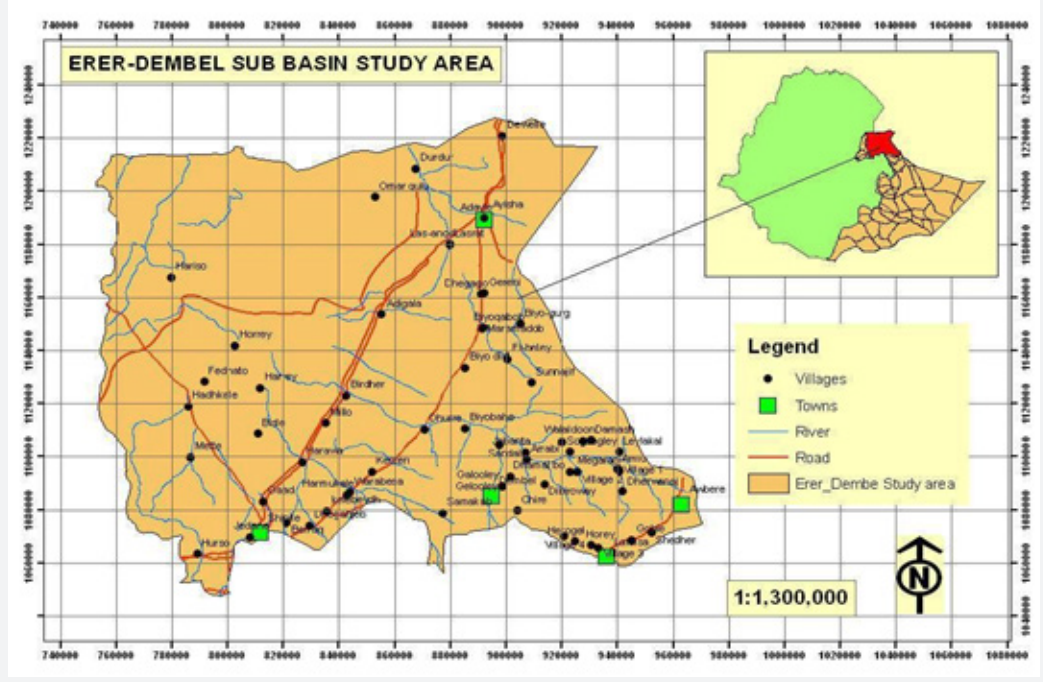

Figure 1: Location map of the Errer-dembel sub-basin.

\section{Results and Discussions}

\section{Types and forms of soil erosion in errer-dembel sub- basin}

Water erosion: Sheet erosion is the dominant form of erosion occurring in all of the area in Errer-dembel sub-basin. However, it is more serious where the vegetation cover is severely depleted especially in overgrazed land. Erosion pedestals with grasses and leaves perched on them, deposition in relatively lower points within and at the boundaries of fields, and exposed roots of trees in all areas of the Errer-dembel sub-basin indicate the severity of the sheet erosion problem. Many areas experiencing heavy livestock grazing pressure turn into bare lands before the rainy seasons. Moreover, trampling by livestock throughout the dry season further pulverizes the soil and both exposes the land in to sheet wash during the rainy season.

Rill erosion: occurs in all areas of the Errer-dembel sub-basin and, is also the important form of erosion. In fact, in almost all of the areas where sheet erosion is occurring one would find symptoms of rill formation. However, rill erosion is more conspicuous where the slope is relatively higher and the run-off faster. These often are areas where concentrated flow enters a natural water course such as a depression along the slope, a previously formed gully, or un-stabilized road side drain.

Gully erosion: Gully erosion is a serious problem in the Errerdembel sub-basin. Gullies are created mainly as a result of either of the following:

a) The concentration of the run-off in natural drainage lines from the surrounding slopping lands which have very little or no vegetation cover and that cuts into the sub soil;

b) Along footpaths, tracks, cattle roots that are regularly used by men, motor and livestock movement particularly to and from watering points, settlement areas and frequently used grazing fields;

c) Inappropriate and un-stabilized road embankments and road side drains and culverts disposing concentrated run-off 
onto unprotected and/or erosion prone un-stabilized sloping areas were also observed in some parts of the Errer-dembel sub-basin.

Gully formations have devastated most areas in the Errerdembel sub-basin. There is very severe gully cutting in Dembel and Awbere Woredas'. Most of the gullies are already developed to irreversible stages with over 10 meter depth and about 20 meter width. In some areas several chains of gully cuttings have formed gorges and hummocks.

Stream bank erosion: The stream bank erosion in many parts of the Errer-dembel sub-basin is causing tremendous damage to graze and croplands lying adjacent to rivers. There is no economically feasible method for controlling bank erosion, and occurrence of ox-bows and meanders in many valley floors, shows that this process is very active. The most casual observation of the braided channels in the valley floors is clear indication that these mass movement processes are the source of the huge amounts of coarse bed load material.

Stream bank erosion is not only disastrous in terms of losing eroded land but also damage of downstream plain land due to sedimentation coarse materials. Stream bank erosion is severe throughout the Errer-dembel sub-basin. However, the wadies and river courses and its tributaries in Shinile Woreda's, Derwenageand-Arabi are extremely eroding adjacent lands. Some of the streams are cutting the banks up to 50meter width and about 10 meter depth and still expanding, thus have already reached irreversible stage.

\section{Wind erosion}

Since Errer-dembel sub-basin areas, is arid and semi-arid land with scarce vegetation cover windy events prevailing in most parts of the year with high speed. In spite, of the shortage of data on wind speed for the other areas in the Errer-dembel sub-basin, wind erosion is considered to be a problem in Aydora, Meto and Hori Pas; and parts of Asbuli, Adigala and Aysha woreda's of the Sub-basin. However, it is more serious in areas of low vegetation cover. According to local informants, the wind in these areas is not Table 1: Area distribution of major soil groups in Erer-Dembel sub-basin.

\begin{tabular}{|c|c|c|c|c|c|}
\hline \multirow{2}{*}{ No } & \multirow{2}{*}{ Major Soil Group (FAO, 1998) } & \multirow{2}{*}{ Identified Soil Units (FAO, 1998) } & \multirow{2}{*}{ Code } & \multicolumn{2}{|c|}{ Area } \\
\hline & & & & На & Percent \\
\hline 1 & Vertisols & Chromic Vertisols & VRcr & 24057.6 & 0.95 \\
\hline 2 & Luvisols & Chromic Luvisols & LVcr & 15850.28 & 0.63 \\
\hline \multirow[t]{2}{*}{3} & Cambisols & Vertic Cambisols & CMvr & 125145.1 & 4.98 \\
\hline & & Eutric Cambisols & CMeu & 80222.19 & 3.19 \\
\hline 4 & Leptosols & Epileptic Leptosols & LPel & 406240.1 & 1.16 \\
\hline \multirow[t]{2}{*}{5} & Fluvisol & Eutric Fluvisol & FLeu & 761166.4 & 30.29 \\
\hline & & Calcaric Fluvisol & FLca & 34539.37 & 1.37 \\
\hline 6 & Solonchaks & Orthic Solonchaks & SOor & 579181.3 & 23.04 \\
\hline 7 & Andosols & Vitric Andosols & ANvi & 14741.4 & 0.58 \\
\hline 8 & Regosols & Eutric Regosols & REeu & 2418.7 & 9.59 \\
\hline
\end{tabular}

only very erosive but also highly damaging to properties. They said, the winds are so strong that sometimes trees are uprooted, and roofs are blown. Moreover, when windy events occur in these areas, it was indicated that the atmosphere suddenly fills with dust, turns to dusty cloudy and even makes movement difficult. Sometimes the cloudy situation is said to last for half an hour and covers very large areas.

\section{Causes and effects of soil erosion}

The interaction of several factors accelerates the process of soil erosion, which in turn accelerates the process of land degradation. The following are among the major causes for accelerated soil erosion in Errer-dembel sub-basin.

Rainfall: in Errer-dembel sub-basin heavy storm characteristic of short period rainfall is a major cause of erosion. Average and maximum daily rainfall is $56.3 \mathrm{~mm}$ and $115 \mathrm{~mm}$ respectively, while minimum daily rainfall is $23 \mathrm{~mm}$.

Overgrazing; as the grazing animal's moves around the field, it tends to exert a considerable pressure on the surface, which affect both the soil and grass/vegetation. In Errer-dembel subbasin the average weight of a mature sheep is about $60-80 \mathrm{~kg}$ that of a mature cow is about $500 \mathrm{~kg}$. Given the total hoof areas of 80 $100 \mathrm{~cm}^{2}$ and $250-350 \mathrm{~cm}^{2}$, respectively, indicates that the animals may exert a force of up to $1600 \mathrm{gcm}^{2}$, In the case of the younger animals, the body weight is low but because the ratio between weight and hoof area remains fairly constant, the pressure exerted on the soil is much the same. The effect of compaction and deformation by trampling are wide ranging. Closure of the pore spaces inhibits root development and reduces plant growth. It increases moisture retention and causes a reduction in infiltration capacity. It destroys soil organism and thereby interferes with organic matter decomposition and nutrient cycling. Ultimately it may lead to changes in grass composition and soil erosion. There is about $50 \%$ loss of dry matter from trampling and soil detachment. Overgrazing has resulted in soil erosion and land degradation in all areas of the Errer-dembel sub-basin with more pronounced effects in Shinile, Aysha Dewele. 


\section{International Journal of Environmental Sciences \& Natural Resources}

\begin{tabular}{|c|c|c|c|c|c|}
\hline 9 & RS & RS & RS & 230407 & 9.16 \\
\hline Total & & & & 2512927 & 100 \\
\hline
\end{tabular}

Erodible nature of the soil: the major soils in the Errerdembel sub-basin area (Table 1) Leptosols, Fluvisols, Cambisol, Regosols, Luvisol Solonchack sand few Andosol. The natural characteristic; friable and loose/massive structure, low shear strength, poor water holding capacity coupled with shallowness and coarse texture (mainly sandy loam) makes the soils of the area to be susceptible to erosion and land degradation.

Deforestation: the emergence of small towns mainly along the roads has increased the demand for forest products for purposes such as construction and fuel wood. Settlers sometimes set fire to the forest surrounding their settlement areas in fear of wild animals. In Errer-dembel sub-basin Charcoal making has significantly contributed to deforestation. All pastoralist interviewed were reported that they do not have alternative income than charcoal making for their daily expenses.

Steep slopes, undulating and rugged terrain: some areas in the Errer-dembel sub-basin have undulating and rugged terrain with hills, hummocks, escarpments, mountains with steep slopes. All these favors erosion and land degradation by different agents including human interference.

Flooding and sedimentation: Flooding in the sub-basin is a problem mainly along the banks of the wadies river and its tributaries. These floods originate from areas within the Region as well as from areas outside the sub-basin. Flooding and sedimentation have damaged the good land by covering/with water (water logging), buring the good and palatable vegetation, encouraging growth of undesirable species, blocking accesses and trekking routes and force rerouting. Land deterioration in Shinile, Hari area due to overflow and sediments deposition which transported from the upland's lands where stones, boulders, silts, sand etc. buried, the once productive grazing land.

Drought: during periods of drought, livestock have often concentrated in areas where water is available, such as the plains along the sides of perennial vegetation and perennial rivers and streams. These areas are subjected to heavy grazing pressures resulting in denudation, which in turn makes them vulnerable to sever wind and water erosion.

Another effect of drought is its direct influence on vegetation. In the absence of moisture most vegetation disappears on its own. The fact that the livestock are desperately feeding on the remnant vegetation (even poorly palatable species) during these times of rainfall shortage forces most plant species to disappear quickly and the land has no protection from the eroding forces of both water and wind.

Change in climate: major climatic elements such as rainfall (daily, mean monthly and mean annual rainfall), temperature (min. max. and average), humidity, wind speed, sunshine hours, of Hurso and Errer station and other nearby stations such as Dire
Dawa and Jigjiga have been reviewed. Review of the last 20years rainfall data reveals that, the intensity of rainfall is decreasing from time to time, whereas evapotranspiration is drastically increasing as a result of increase in temperature and relative humidity. Water balance calculation has shown moisture deficit throughout the year thus aggravate the problem of erosion by decreasing surface cover that obstruct erosion.

Poverty: of all poverty is the fundamental cause of natural resource degradation. Poverty forces the semi nomadic people in the sub-basin to extract as much as they can from the land and it's by products for short term survival without any choice against long term interests.

Generally, in Ethiopia, as in many developing countries, most of the data on the extent of soil degradation is based more on gross estimates than on agro-climatic-ecology based site-specific studies. According to one of these estimates, the erosion hazard assessment of FAO/UNDIP [6], different types of degradation significantly affect some $60 \%$ of the land surface of the country. Of this, about $94 \%$ is due to soil erosion. Considering the relative contribution of water and wind erosions, about $84 \%$ of the erosion induced soil degradation is due to water erosion and about $16 \%$ is a result of wind erosion. Errer-dembel sub-basin is not an exception to this phenomenon, though the relative contribution of water erosion to degradation is expected to be higher due its geomorphological nature.

Estimates by Hurni [4] show that, on grasslands, soil loss rates exceed soil formation rates by a factor of 0.8 to 2.3. These estimates also show that grass lands with altitudes between 500 and 1,000 m.a.s.l and rainfall between 200 and $900 \mathrm{~mm}$ loose up to $0.7 \mathrm{~mm}$ depth of soil each year, while the corresponding soil formation rates are estimated to be 0.3 mmyear $^{-1}$. This corresponds to soil formation and loss rates of 3 and 7 tonsha1 year $^{-1}$, respectively.

Moreover, it should be noted that the consequence, particularly on soil water holding capacity of an annual net decrease of $0.4 \mathrm{~mm}$ of soil depth, in arid and semi-arid environments such as Errerdembel sub-basin, where rainfall is scanty and of very short duration, and evaporation extremely high, is very detrimental. If you leave the scientific aspects and continue discussing the current erosion practice, most of the areas in the sub-basin are suffered from $20-30 \mathrm{~cm}$ depth of soil erosion per annum. This will practically result in bare land.

\section{Soil erosion hazard in the Errer-dembel sub-basin}

The original soil erosion model called Universal Soil Loss Equation (USLE) was empirically derived from more than 10,000 plots and years of runoff and soil loss data contributed from 49 locations in the United States [2]. It is the most widely used erosion model to predict soil loss [7]. USLE was designed to provide a 
convenient tool for soil conservationists and can be used to any geographic region with its modified factors. It has been used in developing conservation plan and land use decisions.

Some recent researches led to a revision of USLE that provides more accurate estimation of soil loss i.e. the Revised Universal Soil Loss Equation (RUSLE). RUSLE has the same formula with USLE but has several improvements in determining factors. Hurni [8] has modified the USLE to fit the Ethiopian conditions. He has modified some of the input factors used by the USLE model like, rainfall erosivity (R), land cover (C) and management (P) factors for the Ethiopian condition.

Therefore, in this review, to assess soil erosion the revised universal soil loss model, which was developed by Wischmeier \& Smith [7] and modified by Hurni [8], to the Ethiopian conditions, was used because of its less input requirement, computational simplicity and wide applicability.

Since the aim of the erosion hazard assessment was to assess relative erosion hazard for use in catchment selection for watershed management interventions, the actual rate of soil loss is not considered as important as indicating relative rates of soil loss. It considered that the Revised Universal Soil Loss Equation
[3] would be suitable and that the inclusion of parameters specifically identified for the Ethiopian situation would give as good an assessment of the actual erosion rates as possible. The RUSLE methodology is based on the Universal Soil Loss Equation [7].

$$
A=R * K * L * S * C * P \text { Equation } 1
$$

Where; $\mathrm{A}=$ total soil loss (tonsha ${ }^{-1} \mathrm{yr}^{-1}$ ), $\mathrm{R}=$ Rainfall erosivity factor, $\mathrm{K}=$ Soil erodibility factor, $\mathrm{L}=$ Slope length factor, $\mathrm{S}=$ Slope gradient factor, $\mathrm{C}=$ Land cover factor and $\mathrm{P}=$ Management factor

a) These concerns have been taken into account in undertaking the erosion hazard assessment has:

b) Updated the rainfall ' $R$ ' factor

c) Re-assessed the soil ' $K$ ' factor in light of comments made in the Abbay Master Plan

d) Used the most recent and detailed Digital Elevation Model (DEM) for the assessment of slope length ' $L$ ' and gradient ' $\mathrm{S}$ ' factors; and

e) Used the most up to date land cover mapping available for the ' $\mathrm{C}$ ' factor and also the management ' $\mathrm{P}$ ' factor.

\section{Rainfall erosivity (R)}

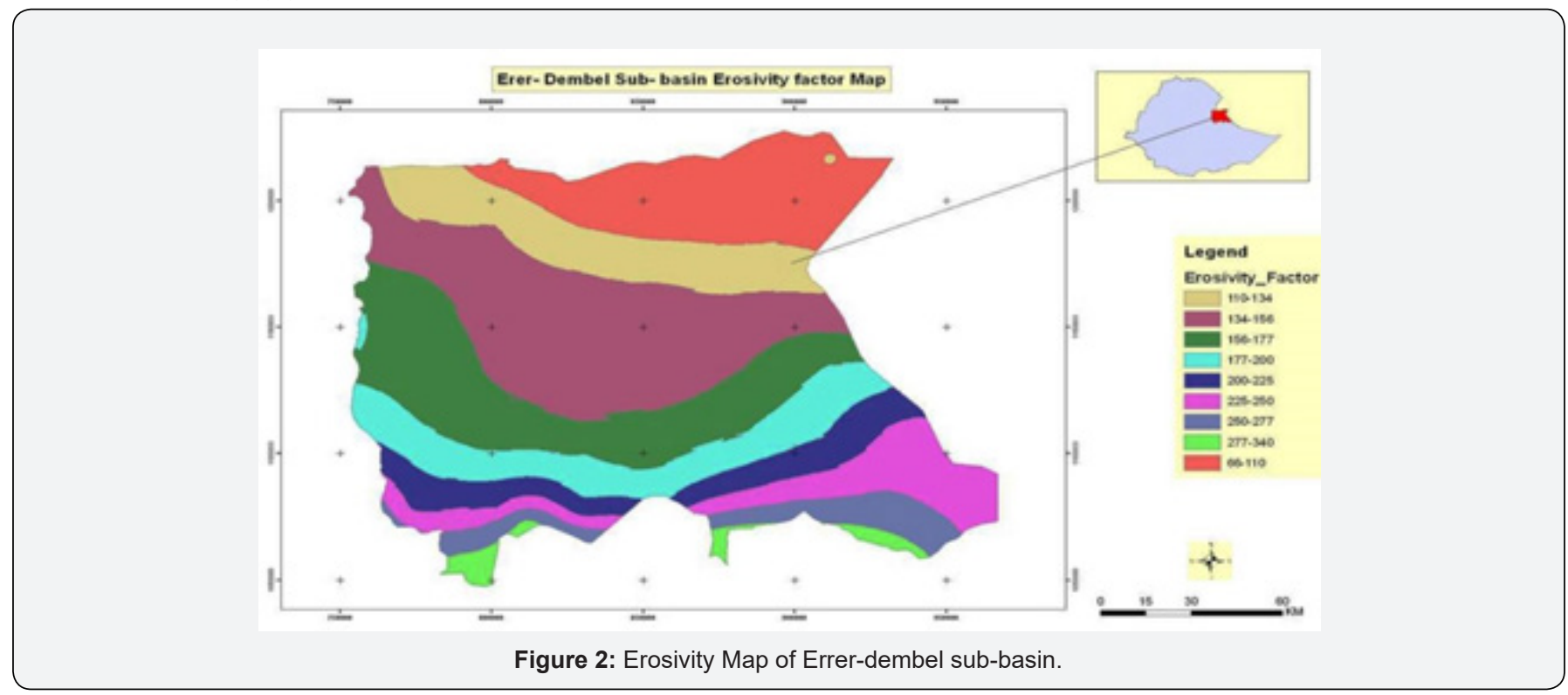

The Woody Biomass Project [9] re-assessed the SCRP/Hurni data above and created a digital rainfall map (Figure 2) with the ' $\mathrm{R}$ ' parameter assessed from the mean annual rainfall by the Equation;

$$
R=(4.883 \mathrm{x}-124.49) / 10 \text { Equation } 2
$$

Where; $\mathrm{x}$ is the mean annual rainfall

The project has collected monthly rainfall data for all stations within the basin into a MS XL Database. The missing data was then interpolated using ArcMap GIS as shown on Figure 2.

\section{Soil erodibility (K)}

In the USLE, the ' $\mathrm{K}$ ' factor is determined from a monograph using values of: percent silt and very fine sand, percent sand, organic matter content, topsoil structure grade; and Permeability grade. In reality, especially at reconnaissance level, these data are often difficult to obtain and may not be suitable for extrapolation from one area to another. For this reason, Hurni [8] derived K values based on easily observable soil colour.

The Abbay Master Plan [10] though calculated $\mathrm{K}$ values for the soil units occurring within the basin and found that whilst some correlated relatively well with SCRP values $[11,12]$ red soils' 


\section{International Journal of Environmental Sciences \& Natural Resources}

calculated $\mathrm{K}$ values were consistently lower that the SCRP K value (0.07-0.1vs 0.25). With other SCRP research data indicating that the USLE monograph methodology consistently underestimated the soil erodibility $\mathrm{K}$ factor, that Luvisols do not correlate well and that Leptosols, Cambisols, Regosols and Fluvisols also have Table 2: Erodiability/K-values of the soils of the sub basin.

\begin{tabular}{|c|c|c|c|c|c|}
\hline SMU & K-Value & SMU & K-Valu & SMU & K-Value \\
\hline SS1-7 & 0.11 & PL1-3 & 0.24 & HI3-3 & 0.29 \\
\hline SS2-7 & 0.13 & PL1-2 & 0.24 & HI3-8 & 0.3 \\
\hline SS3-7 & 0.13 & PL2-8 & 0.24 & PL2-5 & 0.3 \\
\hline PU2-6 & 0.15 & PU4-5 & 0.25 & PU2-4 & 0.34 \\
\hline PL2-7 & 0.2 & HI4-8 & 0.25 & M02-8 & 0.34 \\
\hline HI3-5 & 0.2 & HI3-7 & 0.27 & PL1-4 & 0.21 \\
\hline PL1-1 & 0.21 & PL2-2 & 0.27 & HI1-7 & 0.28 \\
\hline PU2-8 & 0.22 & M03-8 & 0.29 & & \\
\hline
\end{tabular}

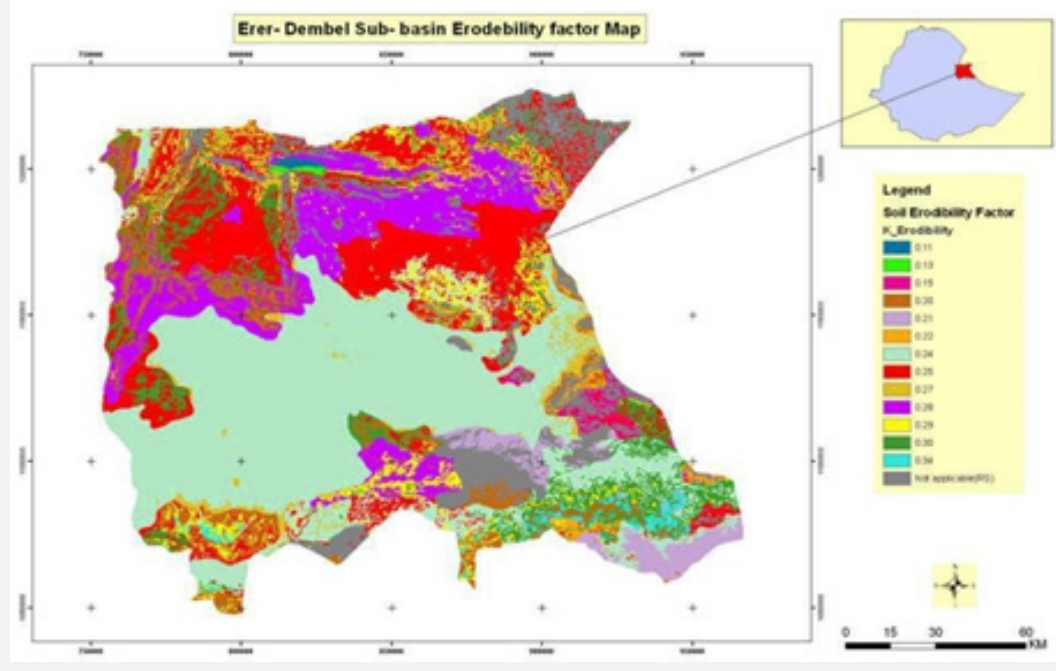

Figure 3: Erodibility Map of Errer-dembel sub-basin.
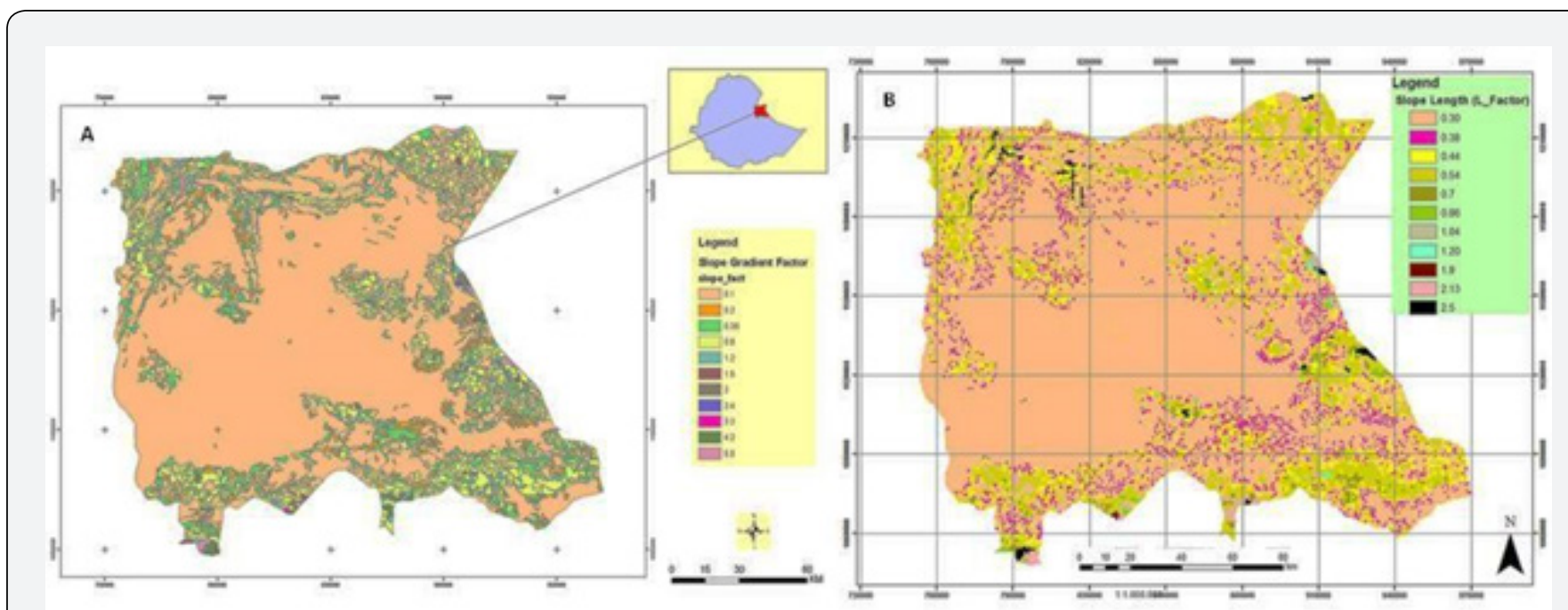

Figure 4: Slope gradient (left-A) and slope length factor (right-B) map of Errer-dembel sub-basin. 


\section{Slope length (L) and gradient (S)}

By using a DEM with $30 \mathrm{~m}$ resolution it was possible to calculate both slope length ' $\mathrm{L}$ ' and gradient ' $\mathrm{S}$ ' rather than having to use a combined factor as has been the case in the past, resulting in far greater accuracy than in previous assessments. Both Reynard et al. [2] \& Nyssen et al. [13] have indicated that above $22 \%$ slope the curve of soil loss versus slope flattens therefore the parameters used have taken this into account and have re-assigned the Hurni slope parameters (Figure 4).

\section{Land cover ( $C$ ) and land management (P)}

As Nyssen et al. [13] commented, the land cover factor ' $\mathrm{C}$ ', is of paramount importance in the determination of erosion hazard assessment because of the large difference between its minimum and maximum values and therefore slight mistakes in land cover mapping can easily result in large over or under estimations of soil loss. For this reason, it was imperative that as accurate and up-to-date land cover data as possible is used and therefore Woody Biomass Project TECSULT [9] data was used.

This data was compiled from satellite imagery mapping with a great deal of field ground-trothing and can therefore be considered to be appreciably more accurate than older data or more contemporary global data. Land Cover parameters were obtained from Halcrow [14] FAO/LUPRD [6], SCRP [12] and Hurni and the WBISPP parameters were also derived using these historical data. The land cover map was shown in Figure 5A. Except in some areas of Lefeissa and Errer there is no land management practice (P) in general. The land management map was shown in Figure 5B.
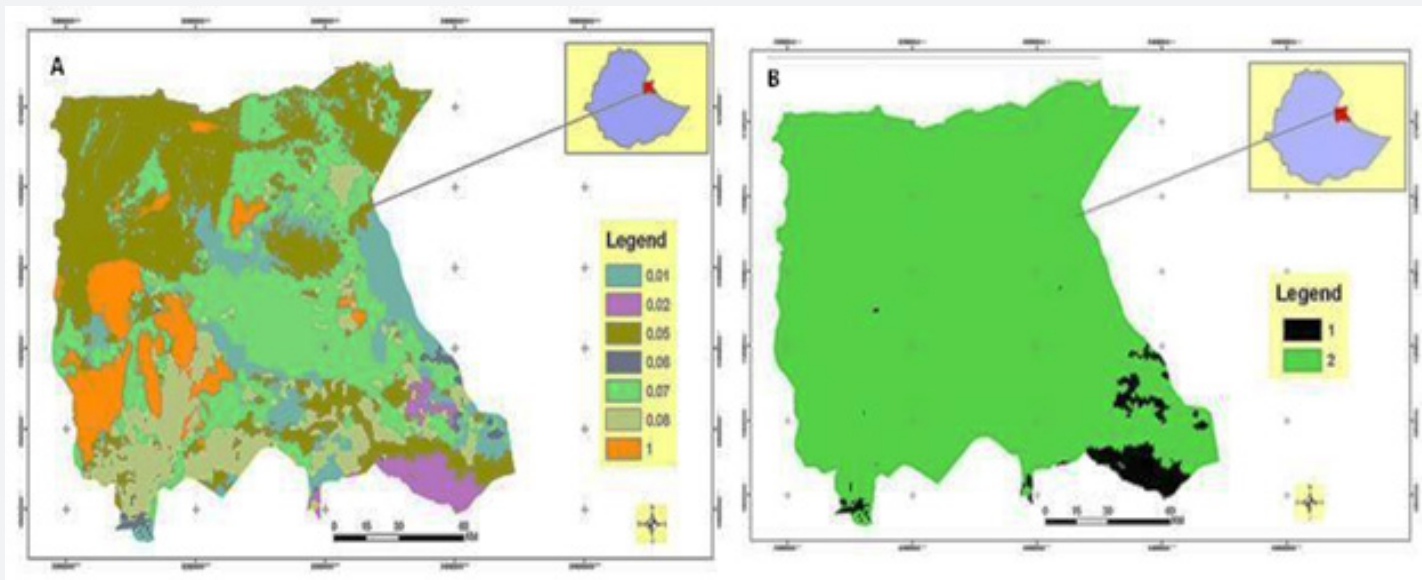

Figure 5: Land Cover (left-A) and land management (right-B) factor of Errer-dembel sub-basin.

\section{Soil loss tolerance and soil formation rate}

\section{Soil loss tolerance}

Soil loss tolerance has to be assessed with the soil formation rates [5] under research plots. Soil loss tolerance may always be as high as the accumulations on the soil surface and the decomposition rate of organic materials. However, if intensive weathering occurs within the soil profile, Soil loss tolerance may even be higher.

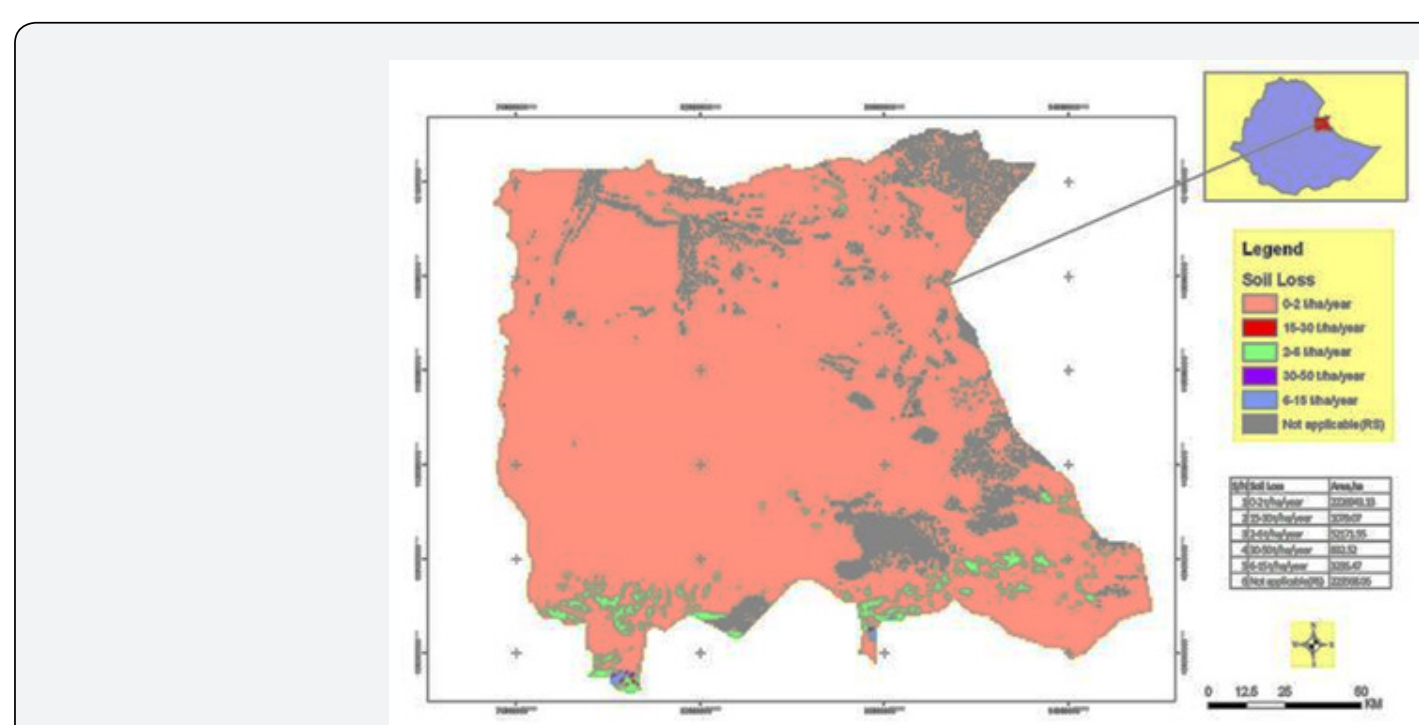

Figure 6: Land use land cover factor map of Errer-dembel sub-basin. 
The maximum soil loss tolerance for tropical regions is 25tonsha-1yr-1 [15]. A commonly used soil loss tolerance rate is $5-12$ tonsha-1yr-1 for shallow to deep soils [16]. The tolerance value for tropical soils has not yet been formulated at international level, but Hurni [17] \& Hudson [18] established annual soil loss tolerance limits that vary between 0.2 and 11 tonsha-1yr-1 [15]. The soil loss tolerance values are used for the determination of critical area of soil erosion in the watershed by comparing soil loss rates with soil loss tolerance. If the soil loss is less than or equal to the soil loss tolerance, the soil loss is still accepted. However, if the soil loss is more than soil loss tolerance, conservation measures to reduce soil erosion should be taken into account until a level of equal or less than the soil loss tolerance has been reached (Figure 6).

\section{Soil formation rate}

An empirical model for the calculation of soil formation rates has been developed for use in the Ethiopian Highlands Reclamation Study in 1983 [19]. The model developed is:

\section{$F=f_{m} * t * r * l * u * d * S * c \quad$ Equation 3}

Where; F=mean annual soil formation rate, $f m=$ maximum soil formation rate, $\mathrm{t}=\mathrm{f}(\mathrm{Ta}), \mathrm{T}=$ mean annual temperature, $\mathrm{r}=\mathrm{f}(\mathrm{Ta})$,
Ta=mean annual Rainfall, l=f(l), L=Length of growing period, $\mathrm{u}=\mathrm{f}(\mathrm{U}), \mathrm{U}=$ soil unit, $\mathrm{d}=\mathrm{f}(\mathrm{D}), \mathrm{D}=$ soil depth, $\mathrm{s}=\mathrm{f}(\mathrm{S}), \mathrm{S}=$ slope gradient and $c=f(C), C=$ land cover and use

Mean annual soil formation rate (fm) has the value 24tonsha$1 \mathrm{yr}-1$ for tropical zone and all other factors receive values between 1 and 1.1 for optimum conditions and decreasing values for less favorable conditions. Thus, optimum temperature of $17.5-22.5^{\circ} \mathrm{C}$ obtain the factor 1 , optimum rainfall over $1950 \mathrm{~mm}$ per year has a factor 1. Optimum length of growing period over 270days has 1. Optimum soil units such as Fluvisols, Nitosols, vertisols, cambisols for best sub units and phases have the value of 1.05. Optimum soil depths more than $100 \mathrm{~cm}$ has 1 . Optimum slope gradient less than $10 \%$ is 1 and land cover, intensive cultivation has 1.1 . The mean annual soil formation rate as shown in the above formula is the product of all 8 factors [20,21].

Using the model, soil formation rate of Errer-dembel subbasin has been calculated having the value $t=0.95, r=0.5, l=0.6$, $\mathrm{u}=0.5, \mathrm{~d}=0.4, \mathrm{~s}=0.5$ and $\mathrm{c}=0.6$. The soil formation rate is in the range of $0.5-4$ tonsha- $1 \mathrm{yr}^{-1}$ and, is far less than soil erosion rate of 5-41tonsha-1yr-1. Thus, the soils of Errer-dembel sub-basin are found to be highly susceptible to soil erosion under any circumstances (Figure 7).

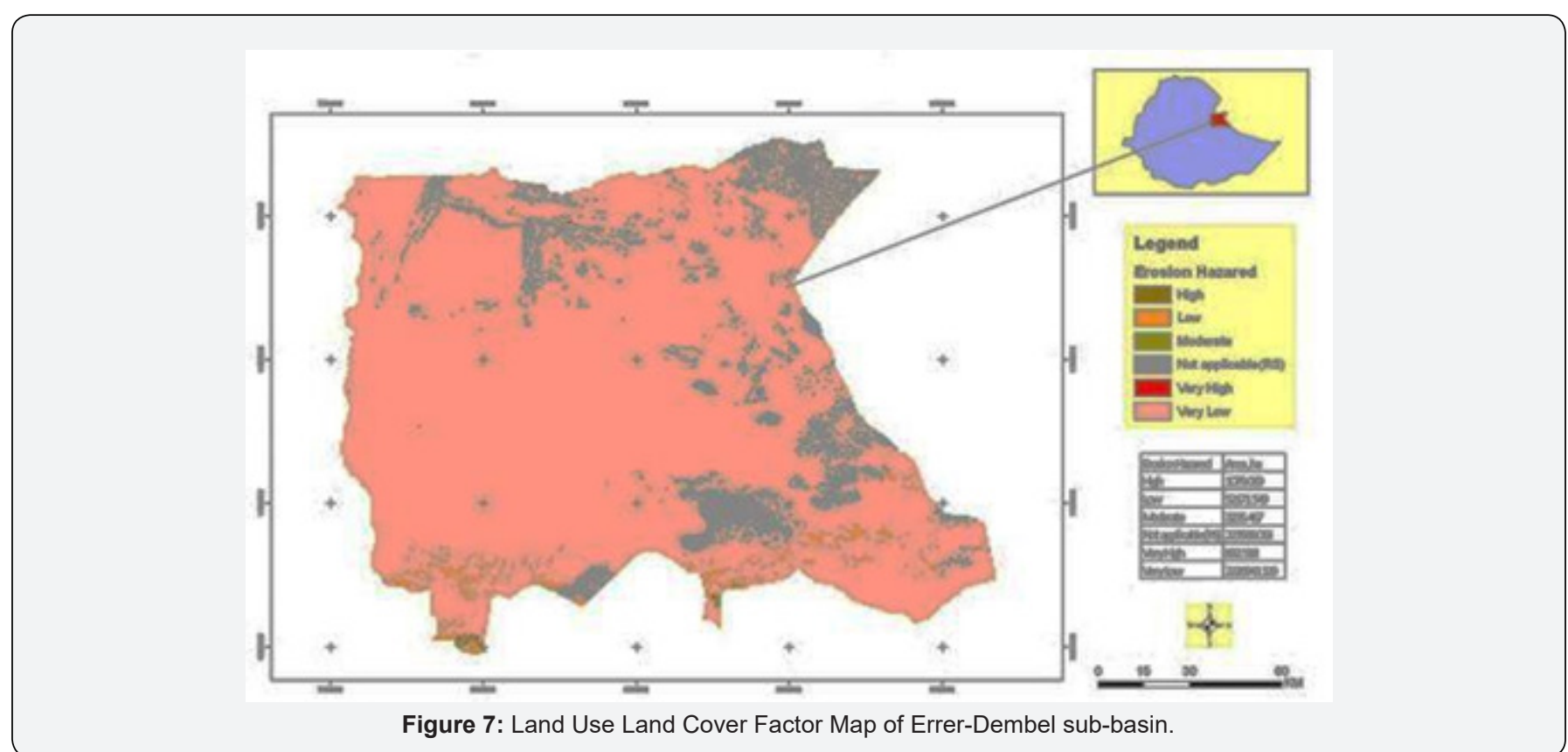

\section{Acknowledgements}

The authors acknowledge the Oromia water works design and supervision enterprise/OWWDSE and Deridawa council for their technical material support and encouragement in carrying out his review work; thanks, are also to Jigjig University and Adigrat University.

\section{References}

1. Hickey R (2000) Slope Angle and Slope Length Solutions for GIS. Journal of Cartography 29(1): 1-8.
2. Reynard KG, Foster GR, Weesies GA, McCool DK, Yoder DC (1997) Predicting Soil Erosion by Water; a Guide to Conservation Planning with the Revised Universal Soil Loss Equation (RUSLE). U.S. Department of Agriculture, Agriculture Handbook No. 703, p. 404.

3. UNEP (1991) Final act of the conference of plenipotentiaries for the adoption of the annexes to the protocol concerning specially protected areas and wildlife in the wider Caribbean region Kingston, 10-11 June 1991.

4. Hurni H (1988) Climate, Soil and Water; Degradation and conservation of the resources in the Ethiopian highlands. Geographical institute University of Berne, hallerstrasse 12.3012 Berne, Switzerland. 
5. Hurni H (1983) Soil formation and soil loss tolerance estimation model modified to Ethiopian conditions. Assistance to land use planning; Field document.

6. Food and agriculture organization of the united nations/FAO (1986) Ethiopian highlands reclamation study, Rome. Final report Vol 1 \& 2, ag: utf/eth/o37/eth.

7. Wischmeier WH, Smith DD (1978) Predicting rainfall erosion losses; a guide to conservation planning Series. Agriculture Handbook No. 537. USDA, Washington DC, USA.

8. Hurni H (1985) Soil Conservation Manual for Ethiopia, Ministry of Agriculture: Addis Ababa, Ethiopia.

9. USDA (1979) Engineering field manual for conservation practices, USDA, Soil conservation service; Woody Biomass Inventory and Strategic Planning Project (2004) Executive Summary Methodologies for Land use systems, Socio-economic Survey, MoA- TECSULT.

10. Master Plan for the Development of Surface Water Resources in the Awash Basin (1989) Final Report, Volume 6, EVDSA, HALCRO, Peoples Democratic Republic of Ethiopia, Ethiopia.

11. Soil Conservation Research Project/SCRP; Research progress reports for the periods, 1982-1989.

12. Soil and water conservation Guideline for Ethiopia (2001) Natural Resources Management and Regulatory Department, Ministry of Agriculture.

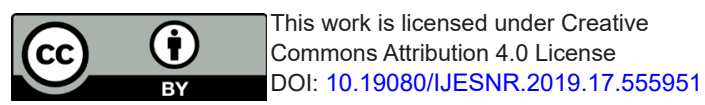

13. Nyssen J, Getachew S, Nurehusen T (2008) An upland farming system under transformation: Proximate causes of land use change in Bela-Welleh catchment (Wag, Northern Ethiopian Highlands). Soil Tillage Res 103(2): 231-238.

14. Hal crow (1989) Landslides and Climate Change: Challenges and Solutions: Proceedings. CRC Press, Boca Raton, Florida, United States.

15. Ringo (1999) Assessment of soil erosion in the turasha catchment in the lake naivasha area Kenya.

16. Lal R (1984) Soil erosion from arable lands and its control. Advances in Agronomy 37: 183-248.

17. Hurni H (1980) A nomography for the design of lobour intencive soil conservation rainfied cultivation.

18. Hudson (1986) Soil Conservation. ( $2^{\text {nd }}$ edn), B.T. bats ford, London, UK.

19. Barber GR (1984) Generalized soil physical erosion hazard index ma, the Ethiopian Highlands Reclamation Study.

20. Hurni H (1988) 0044egradation and Conservation of the Resources in the Ethiopian Highlands. Mountain Research and Development 8(2/3): 123-130.

21. Hurni, H (1983) Soil Formation Rate in Ethiopia, Working Paper 2, Food and Agriculture Organization of the United Nations (FAO)/Ministry of Agriculture (MOA) Joint Project, Ethiopian Highlands Reclamation Study, Addis Ababa.

\begin{tabular}{l} 
Your next submission with Juniper Publishers \\
will reach you the below assets \\
- Quality Editorial service \\
- Swift Peer Review \\
- Reprints availability \\
- E-prints Service \\
- Manuscript Podcast for convenient understanding \\
- Global attainment for your research \\
- Manuscript accessibility in different formats \\
( Pdf, E-pub, Full Text, Audio) \\
- Unceasing customer service \\
Track the below URL for one-step submission \\
https://juniperpublishers.com/online-submission.php \\
\hline
\end{tabular}

